\title{
Conceptualizing the Dynamics of Development in the 21st Century: Process, (Inter)Action, and Complexity
}

\author{
David C. Witherington ${ }^{a} \quad J^{\prime}$ Bon Bom ${ }^{b}$ \\ a University of New Mexico, Albuquerque, NM, USA; \\ bUniversiteit Utrecht, Utrecht, The Netherlands
}

A principal question of human development is how new patterns and levels of organization come into being during an individual's development (Anastasi, 1958; Wolff, 1987). Throughout much of the last century, answers to this question all too often evinced a static conceptualization of development. Developmental change was viewed as little more than a read-out or translation of pre-existent "design" information contained in the genome, environment, or some additive combination of the two (Levins \& Lewontin, 1985; Oyama, 1985; Thelen \& Smith, 1994).

Over the past quarter century, however, accounts of processes that take the $d y$ namics of development seriously have enjoyed increasing prominence in the field (e.g., Thelen \& Smith, 1994; Magnusson \& Cairns, 1996; Fischer \& Bidell, 1998; Bickhard, 2000; van Geert, 2000; Adolph \& Robinson, 2008; Nesselroade \& Molenaar, 2010; Di Paolo, Buhrmann, \& Barandiaran, 2017). Such "dynamics" orientations to process ground themselves in the embodied and embedded activity of individuals in time and context. They embrace notions like emergence and self-organization, focusing on how new patterning in individual activity (both in real and developmental time) arises through nonlinear relations among component processes that span the individualin-context system - without being in any way prefigured or prescribed by any of the component processes themselves. And they embrace variability in real-time functioning, both within and across individuals and contexts.

Metatheoretically speaking, dynamics orientations to the study of development eschew an ontology of substance in favor of a process ontology (Rescher, 1996; Bickhard, 2008). As the default centerpiece of scientific thought since the 17th century, substance ontologies reduce all complexity in the world to a foundational set of unchanging material entities or things (e.g., atoms) that exist independently of one another. With stasis as the world's ontologically primal state, change emerges only as a secondary consequence of the rearrangement of these elements relative to one another - a rearrangement consisting of external relations among fixed entities. By contrast, process ontologies regard processes, not things, as foundational to existence.

\section{KARGER}

E-Mail karger@karger.com www.karger.com/hde (c) 2019 S. Karger AG, Basel

\footnotetext{
David Witherington

Department of Psychology, MSC03-2220

University of New Mexico

Albuquerque, NM 87131-1161 (USA)

E-Mail dcwither@unm.edu
} 
Activity and change, existing at various, interpenetrating levels of organization, assume ontological primacy, and things in themselves emerge only secondarily as manifestations of relative stability in communities of processes (Rescher, 1996; Overton, 1998; Bickhard, 2008; Overton, 2015).

Notably, the burgeoning dynamics orientation and attendant process ontology of today's developmental science are not without historical precedent. In the early decades of the last century, influential process ontologies framed in terms of an organicist world view (Pepper, 1942) arose in both biology and the study of human development. Forged in the wake of physics' quantum revolution and publication of Whitehead's seminal Science and the Modern World (1925), these organicist approaches sought to overturn orthodox science's machine metaphor of the world with an alternative focus on principles of dynamic process, organization, and wholeness (Nicholson, 2018). In the context of the biological sciences, this translated into nonmechanistic, holistic conceptualizations of organisms as irreducible systems actively maintaining their own form and organization through ceaseless exchange of material and energy with the world (e.g., von Bertalanffy, 1933; Weiss, 1973).

Likewise, in the study of human development, founders of the discipline such as Piaget (1952), Werner (1957), and Vygotsky (1978) emphasized that developmental change arises from the constructive activity of developmental processes themselves (van Geert, 1998; Toomela, 2009). They conceptualized the dynamics of constructive activity in terms of a hierarchy of processes, from organisms dynamically engaging their world in real-time activity (i.e., synchronic processes) to broader, more abstracted levels of developmental time dynamics (i.e., diachronic processes, like Werner's [1957] orthogenetic principle or Piaget's [1985] equilibration or reflective abstraction [Piaget, 2001, see Boom, 2003, 2009]). Critically, these renowned architects of classic systems approaches regarded any complete understanding of process dynamics in development as necessitating a formal or structural orientation, involving explanatory appeals to sequences of directional change in levels of organization (e.g., stages of development) and the positing of ideal end points (e.g., the adult form or stage) for rendering such sequences explicable (Witherington, 2015; Witherington \& Heying, 2015).

By the mid 20th century, development of the digital computer and the information-processing machine metaphor that it spawned ushered in a thoroughgoing revival of mechanistic thought and substance ontology across the sciences (Bruner, 1990; Wright \& Bechtel, 2007; Nicholson, 2018). The influence of organicist, systemsoriented thought suffered significantly as a consequence. However, as major advances in the mathematical understanding of nonlinear systems migrated from the physical to the biological and psychological sciences, new dynamic systems approaches emerged in developmental science during the waning years of the 20th century, sparking a revival of interest in dynamics orientations (e.g., Fogel et al., 1992; Thelen \& Smith, 1994; van Geert, 1994). This rekindling of interest in dynamics orientations was itself coincident with broader, metatheoretical advancement of a processrelational paradigm that espoused substituting a "spontaneously active (dynamic), changing (developing), relational, holistic (integrated) system" conceptualization of the world for that of orthodox science's Newtonian-Cartesian inspired metaphysics and its mechanistic outlook (Overton \& Lerner, 2012, p. 376; see also Overton, 1998, 2015). Efforts to actively promote such metatheoretical advancement have, in fact, gained considerable traction of late in a variety of fields, including biology and chem- 
istry (Stein, 2004; Woese, 2004; Nicholson \& Dupré, 2018). As calls for renewed commitment to process ontology accelerate across the sciences, it seems more critical than ever to examine, at a systematic, conceptual level, the various kinds of dynamics orientations that make up developmental science's current landscape. The purpose of this special issue is to do just that.

We specifically examine four different, influential approaches to conceptualizing developmental dynamics in this issue - namely, dynamic systems, ecological, enactive, and interactivist perspectives. Each approach is articulated by a key, internationally renowned proponent of the perspective - respectively, Paul van Geert, Karen Adolph, Ezequiel Di Paolo, and Mark Bickhard. To highlight points of conceptual convergence and divergence across the four perspectives, we asked each of these authors to structure his/her perspective treatment around answers to the following five sets of fundamental questions:

Questions pertaining to dynamics and causality: What does it mean to study the dynamics of development? How does your dynamics orientation differ from traditional, "cause versus effect" or "intervening variable" approaches to the study of mechanisms and processes in psychology? How is causality conceptualized in your dynamics orientation, and what are the implications of this conceptualization for our understanding of process in development? How does the study of dynamics differ from the study of mechanisms in machines? How do the dynamics of organic systems differ from those of inorganic systems (or do they)?

Questions pertaining to dynamics and the nature of development: With respect to your dynamics orientation, what does it mean for a phenomenon to develop? What kinds of change over time constitute developmental change? What changes with, or emerges from, development? Do you consider it necessary to distinguish between dynamics at the level of real-time change (the generation of specific organismic actions in adaptation to real-time contexts) and dynamics at higher "emergent" levels of organization (the emergence of new organismic skills and organizations of ability during an organism's lifespan)? Or are developmental dynamics nothing more than real-time dynamics added up over time? Is there a privileged level of analysis (i.e., the cellular level, the organismic level, the level of action-in-context, the level of organism - world relations, etc.) for studying the dynamics of psychological functioning and development?

Questions pertaining to a process philosophy: A focus on the dynamics of development invokes a process ontology (in which time and variability are taken seriously) rather than a substance ontology (in which time and variability are explained away). From the vantage point of your dynamics orientation, what does it mean for the study of dynamics to involve a process rather than a substance ontology? What does it mean to take time and variability seriously? Catchphrases like "embodiment" and "embeddedness" are also routinely associated with a focus on developmental dynamics. How are these terms conceptualized in your dynamics orientation? How are other terms like "novelty," "nonlinearity," "complexity," "system," and "emergence," conceptualized in your dynamics orientation?

Questions pertaining to dynamics and classic systems approaches: To what extent is your dynamics orientation compatible with classic organicist/systems approaches to development (e.g., Piaget, Werner, von Bertalanffy)? More specifically, does your dynamics orientation relate to an understanding of development framed in terms of psychological structures, stages, irreversibility, and directionality? Is the idea of 
higher levels of complexity (higher stages, hierarchy, etc.) compatible with your view of dynamics? In what sense? Does the organicist view of organisms as "integrated wholes" factor into your dynamics orientation? Why or why not? Are organisms reducible to their activities in context?

Questions pertaining to the methodology and analysis of dynamics: What does your dynamics orientation entail for developmental methodology and analysis, and, more generally, for orthodox scientific approaches to psychological functioning and development like the hypotheticodeductive method? What sorts of methods and analyses are and are not appropriate for the study of dynamics in development? What are appropriate units of analysis for the study of dynamics in development?

In his contribution, van Geert enlists the format of an imaginary interview (by way of a philosophical dialogue) to methodically and insightfully address these sets of questions; as such, his contribution serves as the most thoroughgoing introduction to the study and conceptualization of developmental dynamics in this special issue. Adolph returns to basics for her contribution in the sense that she focuses on the only processes that we can really observe, namely bodily movements. Her aim is to systematically elucidate the specific domain of learning in development (involving flexibility) much more than to try to explain it all, and her impressive empirical work in her famous baby lab is a testament to the success of this perspective. For his part, Di Paolo seeks to extend beyond the basics in order to take the full complexity of life into account. Nevertheless, he starts like Adolph with early development, seeking to understand (model or explain) steps in developing sensorimotor agency. But this is just the beginning of an ambitious research program. He convincingly demonstrates the incredible complexity that developmental scientists need to consider in order to understand agency, development, and reflective capabilities. Integrating strands from many different scientific pursuits, Di Paolo's enactive approach is grounded in dynamical systems theory, organizational approaches to biology, and phenomenology. Finally, Bickhard returns to the very basics of basics in his contribution. He develops his arguments from the starting point of far-from-thermodynamic equilibrium organizations to argue that we need even more than dynamics to model development. Cutting across our five sets of questions, he points to emergent normative processes and directionality as constitutive of development and emphasizes learning to learn, both constrained and constituted by reflection, as a major factor in understanding developmental phenomena, in addition to process dynamics.

Following these four perspective papers are commentaries by two other leading authorities on the study of developmental dynamics: Catherine Raeff and John Spencer. In their commentaries, both Raeff and Spencer synthetically articulate points of convergence and divergence across the perspective papers, highlight lacunae that need to be addressed, and offer their own unique vantage points on the focal questions that motivate this special issue. The special issue then concludes with our own look at how developmental science's current dynamics landscape both extends and departs from past dynamics orientations in the field, with a discussion of some pressing conceptual challenges that lie ahead for the study of developmental dynamics and process ontological frameworks more generally. 


\section{References}

Adolph, K. E., \& Robinson, S. R. (2008). In defense of change processes. Child Development, 79(6), 16481653. https://doi.org/10.1111/j.1467-8624.2008.01215.x

Anastasi, A. (1958). Heredity, environment, and the question how? Psychological Review, 65(4), 197-208. https://doi.org/10.1037/h0044895

Bickhard, M. H. (2000). Emergence. In P. B. Anderson, C. Emmeche, N. O. Finnemann, \& P. V. Christiansen (Eds.), Downward causation: Minds, bodies and matter (pp. 322-348). Oxford, UK: Aarhus University Press.

Bickhard, M. H. (2008). Issues in process metaphysics. Ecological Psychology, 20(3), 252-256. https://doi. org/10.1080/10407410802189273

Boom, J. (2003). Individualism and collectivism: A dynamic systems interpretation of Piaget's interactionism. In J. I. M. Carpendale \& U. Müller (Eds.), Social interaction and the development of knowledge: Critical evaluation of Piaget's contribution (pp. 67-85). Mahwah, NJ: Erlbaum. https://doi. org/10.4324/9781410609649-4

Boom, J. (2009). Piaget on equilibration. In U. Müller, J. Carpendale, \& L. Smith (Eds.), The Cambridge companion to Piaget (pp. 132-149). Cambridge, UK: Cambridge University Press. https://doi. org/10.1017/CCOL9780521898584.006

Bruner, J. (1990). Acts of meaning. Cambridge, MA: Harvard University Press.

Di Paolo, E. A., Buhrmann, T., \& Barandiaran, X. E. (2017). Sensorimotor life: An enactive proposal. Oxford, UK: Oxford University Press. https://doi.org/10.1093/acprof:oso/9780198786849.001.0001

Fischer, K. W., \& Bidell, T. R. (1998). Dynamic development of psychological structures in action and thought. In W. Damon (Series Ed.) \& R. M. Lerner (Vol. Ed.), Handbook of child psychology: Vol. 1. Theoretical models of human development (5th ed., pp. 467-561). Hoboken, NJ: Wiley \& Sons.

Fogel, A., Nwokah, E., Dedo, J. Y., Messinger, D., Dickson, K. L., Matusov, E., \& Holt, S. A. (1992). Social process theory of emotion: A dynamic systems approach. Social Development, 1(2), 122-142. https:// doi.org/10.1111/j.1467-9507.1992.tb00116.x

Levins, R., \& Lewontin, R. (1985). The dialectical biologist. Cambridge, MA: Harvard University Press.

Magnusson, D., \& Cairns, R. B. (1996). Developmental science: Toward a unified framework. In R. B. Cairns, G. H. Elder, Jr., \& E. J. Costello (Eds.), Developmental science (pp. 7-30). Cambridge, UK: Cambridge University Press. https://doi.org/10.1017/CBO9780511571114.003

Nesselroade, J. R., \& Molenaar, P. C. M. (2010). Emphasizing intraindividual variability in the study of development over the life span: Concepts and issues. In W. F. Overton (Vol. Ed.) \& R. M. Lerner (Ed.in-Chief), The handbook of lifespan development: Cognition, biology, and methods, Vol. 1 (pp. 30 54). Hoboken, NJ: Wiley. https://doi.org/10.1002/9780470880166.hlsd001002

Nicholson, D. J. (2018). Reconceptualizing the organism: From complex machine to flowing stream. In D. J. Nicholson \& J. Dupré (Eds.), Everything flows: Towards a processual philosophy of biology (pp. 139-166). Oxford, UK: Oxford University Press. https://doi.org/10.1093/oso/9780198779636.001.0001

Nicholson, D. J., \& Dupré, J. (Eds.). (2018). Everything flows: Towards a processual philosophy of biology. Oxford, UK: Oxford University Press. https://doi.org/10.1093/oso/9780198779636.001.0001

Overton, W. F. (1998). Developmental psychology: Philosophy, concepts, and methodology. In W. Damon (Series Ed.) \& R. M. Lerner (Vol. Ed.), Handbook of child psychology: Vol. 1. Theoretical models of human development (5th ed., pp. 107-188). Hoboken, NJ: Wiley \& Sons.

Overton, W. F. (2015). Processes, relations, and relational-developmental-systems. In W. F. Overton \& P. C. M. Molenaar (Vol. Eds.) \& R. M. Lerner (Ed.-in-Chief), Handbook of child psychology and developmental science: Vol. 1. Theory \& method (7th ed., pp. 9-62). Hoboken, NJ: Wiley \& Sons. doi: https:// doi.org/10.1002/9781118963418.childpsy102

Overton, W. F., \& Lerner, R. M. (2012). Relational developmental systems: A paradigm for developmental science in the postgenomic era. Behavioral and Brain Sciences, 35(5), 375-376. https://doi.org/10.1017/ S0140525X12001082

Oyama, S. (1985). The ontogeny of information: Developmental systems and evolution. Cambridge, UK: Cambridge University Press.

Pepper, S. C. (1942). World hypotheses: A study in evidence. Berkeley, CA: University of California Press.

Piaget, J. (1952). The origins of intelligence in children. New York, NY: International Universities Press. https://doi.org/10.1037/11494-000

Piaget, J. (1985). The equilibration of cognitive structures: The central problem of intellectual development. Chicago, IL: University of Chicago Press. (Original work published 1975)

Conceptualizing the Dynamics of Development in the 21 st Century
Human Development 2019;63:147-152 DOI: 10.1159/000504097 
Piaget, J. (2001). Studies in reflecting abstraction (R. L. Campbell, Trans. \& Ed.). New York, NY: Psychology Press. (Original work published 1977)

Rescher, N. (1996). Process metaphysics: An introduction to process philosophy. Albany, NY: State University of New York Press.

Stein, R. L. (2004). Towards a process philosophy of chemistry. HYLE. International Journal for Philosophy of Chemistry, 10, 5-22.

Thelen, E., \& Smith, L. B. (1994). A dynamic systems approach to the development of cognition and action. Cambridge, MA: MIT Press. https://doi.org/10.7551/mitpress/2524.001.0001

Toomela, A. (2009). How methodology became a toolbox - and how it escapes from that box. In J. Valsiner, P. C. M. Molenaar, M. C. D. P. Lyra, \& N. Chaudhary (Eds.), Dynamic process methodology in the social and developmental sciences (pp. 45-66). New York, NY: Springer. https://doi. org/10.1007/978-0-387-95922-1_3

van Geert, P. (1994). Dynamic systems of development: Change between complexity and chaos. New York, NY: Harvester.

Van Geert, P. (1998). We almost had a great future behind us: The contribution of non-linear dynamics to developmental-science-in-the-making. Developmental Science, 1(1), 143-159. https://doi. org/10.1111/1467-7687.00020

Van Geert, P. (2000). The dynamics of general developmental mechanisms: From Piaget and Vygotsky to dynamic systems models. Current Directions in Psychological Science, 9(2), 64-68. https://doi. org/10.1111/1467-8721.00062

Von Bertalanffy, L. (1933). Modern theories of development: An introduction to theoretical biology. London, UK: Oxford University Press.

Vygotsky, L. S. (1978). Mind in society: The development of higher psychological processes. Cambridge, MA: Harvard University Press.

Weiss, P. A. (1973). The science of life: The living system - A system for living. Mount Kisco, NY: Futura Publishing Company.

Werner, H. (1957). The concept of development from a comparative and organismic point of view. In D. B. Harris (Ed.), The concept of development: An issue in the study of human behavior (pp. 125148). Minneapolis, MN: University of Minnesota Press.

Whitehead, A. N. (1925). Science and the modern world. New York, NY: The Free Press.

Witherington, D. C. (2015). Dynamic systems in developmental science. In W. F. Overton \& P. C. M. Molenaar (Vol. Eds.) \& R. M. Lerner (Ed.-in-Chief), Handbook of child psychology and developmental science: Vol. 1. Theory \& method (7th ed., pp. 63-112). Hoboken, NJ: Wiley \& Sons. https://doi. org/10.1037/gpr0000033

Witherington, D. C., \& Heying, S. (2015). The study of process and the nature of explanation in developmental science. Review of General Psychology, 19(3), 345-356. https://doi.org/10.1037/gpr0000033

Woese, C. R. (2004). A new biology for a new century. Microbiology and Molecular Biology Reviews, 68(2), 173-186. https://doi.org/10.1128/MMBR.68.2.173-186.2004

Wolff, P. H. (1987). The development of behavioral states and the expression of emotions in early infancy: New proposals for investigation. Chicago, IL: University of Chicago Press.

Wright, C., \& Bechtel, W. (2007). Mechanisms and psychological explanation. In P. Thagard (Ed.), Handbook of the philosophy of science: Vol. 4. Philosophy of psychology and cognitive science (pp. 31-79). New York, NY: Elsevier. doi: https://doi.org/10.1016/B978-044451540-7/50019-0 